\title{
Is CSR Really Profitable? Evidence From Korea
}

Eunho Cho, Assistant Professor, New York Institute of Technology, Nanjing Campus, China Hayeon Park, Ph. D. Candidate, Sogang University, South Korea

\begin{abstract}
We empirically investigate whether corporate social responsibility (CSR) is really profitable in Korea. Specifically, we examine whether a potential measurement problem of CSR score measured by KEJI (Korea Economic Justice Institute) index affects the relationship between CSR and corporate financial performance (CFP). The empirical results regarding the relationship between CSR and CFP in prior studies have been inconsistent. Although some studies (e.g. Waddock \& Graves, 1997) point out that the potential measurement problem of CSR score is likely to be an important factor to resolve the issue of mixed results, CSR measurement problem to date draws little attention from researchers particularly in Korea setting. We suspect that prior studies that report positive relationship between CSR and CFP using KEJI index is biased upward due to potential measurement problem of KEJI index that includes operating performance component. To examine this issue, we employ an adjusted CSR score which excludes operating performance component included in the unadjusted CSR score to mitigate measurement problem that can show a positive upward bias in the relationship between CSR and CFP in the prior studies.
\end{abstract}

We employ the sample data of 1,301 firm-year observations of manufacturing firms listed in Korea Stock Price Index (KOSPI) market during 2005-2010. Using adjusted CSR score, we find that the positive CSR-CFP relationship significantly weakens compared to unadjusted CSR score. This result remains robust after we perform various sensitivity tests. This study suggests that CSR measurements problem is likely to distort the relationship between CSR and CFP in Korea setting. This study's main contribution is to provide evidence on the measurement problem of KEJI CSR score in the study on the relationship between CSR and CFP.

Keywords: Corporate Social Responsibility; Performance; Measurement Problem

\section{INTRODUCTION}

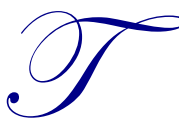

his paper examines whether corporate social responsibility (CSR) is really profitable in Korea. Specifically, we investigate whether the relationship between CSR and corporate financial performance (CFP) is affected by potential measurement problem of CSR scores measured by KEJI (Korea Economic Justice Institute) index in Korea setting. During the last four decades, stakeholders such as customers, employees, suppliers, and community groups have been asking firms to undertake CSR activities (McWilliams \& Siegel, 2000). Some firms have proactively made an effort to meet these demands by investing more resources to CSR activities. Other firms have resisted insisting that investments on CSR activities do not benefit them to accomplish their goal to maximize profits.

Reflecting these concerns in the business, researchers have primarily explored whether the relationship between CSR and CFP exists. However, they have not reached agreement on the definite relationship between two variables in international setting (Cochran \& Wood, 1984; Akpinar et al., 2008; Hull \& Rothenberg, 2008; Aguinis \& Glavas, 2012) as well as Korea setting (J.-S. Choi et al., 2010; Heo \& Chung, 2010; Jang \& Choi, 2010; Na \& Hong, 2011). Despite the inconsistent results, in Korea setting, the majority of studies to date report the positive relationship between CSR and CFP. 
Does CSR really contribute to enhancing firm value or increasing operating income in Korea setting? Is there no measurement problem in CSR score? If it exists, does the positive relationship maintain when adjusted CSR score is used? Waddock and Graves (1997) suggest CSR measurement problem is related to mixed results on the relationship between CSR and CFP. In Korea setting, prior studies have been widely employing KEJI CSR score to measure the level of a firm's CSR activities (e.g. Black et al., 2006; J.-S. Choi et al., 2010; Heo \& Chung, 2010; Oh et al., 2011; B. B. Choi et al., 2013; H. Choi \& Moon, 2013).

We suspect that prior studies that report positive relationship between CSR and CFP using KEJI index is biased upward due to potential measurement problem of KEJI index that includes operating performance component. Then, our research question is "Does KEJI index have the measurement problem to proxy for the level of CSR activities in explaining the CSR-CFP relation? If yes, does the measurement problem significantly affect the positive relationship between CSR and CFP reported in prior studies? Given the strong impact of CSR score on CFP, it is meaningful to assess the measurement problem of KEJI CSR score. However, little study to date has addressed the KEJI index measurement problem in Korea setting. Moreover, C. H. Kim et al. (2013, p. 2588) point out that Korean firms' CSR activities tend to be a short term version with public relations focus because CSR in Korea is driven by government and societal regulative and normative pressures. This implies that the relationship between CSR and CFP in Korea is not necessarily positive.

Although prior studies employ unadjusted CSR score to measure a firm's CSR activities, we need to use adjusted CSR score to correct the potential measurement problem of unadjusted CSR score for the following reasons. First, unadjusted CSR scores have the measurement problem to proxy for CSR activities in the study on the relationship between CSR and CFP because unadjusted CSR score contains operating performance related measures (i.e. economic development contribution) ${ }^{i}$. If operating performance measures are included, they may result in positive upward bias for the relationship between CSR and CFP. For example, if a firm realizes high earnings, it is likely to receive better CSR scores simply because of high earnings, leading to the positive upward bias for the relationship between CSR and CFP. In order to correct the measurement problem and calculate the adjusted CSR score, we exclude operating performance measures (i.e. economic development contribution) from the unadjusted CSR score.

Second, KLD ratings widely used for CSR studies (e.g. Margolis \& Walsh, 2001; Mattingly \& Berman, 2006 ) in the U.S. do not include operating performance measures to proxy for the extent of the firm's CSR activities. That is, the KLD ratings are not substantially influenced by a firm's financial success (Mattingly \& Berman, 2006, p. 21). Specifically, KLD ratings consist of community relations, employee relations, environment, product, treatment of women and minorities, military contracts, nuclear power, and South Africa (Graves \& Waddock, 1994, p. 1038). ${ }^{\text {ii }}$

Third, the KEJI institution decides to exclude the economic development contribution category from the revised KEJI index in 2012, because economic development contribution category tends to be related to operating performance and thereby giving better scores to firms realizing high earnings (KEJI, 2012, p. 15). ${ }^{\text {iii }}$ In this study, we examine whether adjusted CSR score weakens the positive relationship between CSR and CFP reported in the prior studies in Korea setting.

We use the sample of 1,301 firm-year observations of Korean listed manufacturing firms during the period of 2005-2010. Both adjusted and unadjusted KEJI CSR scores are used to proxy for the level of firm's CSR activities. We use Tobin's Q and ROA to measure a firm's financial performance. We find that based on unadjusted CSR score, CSR activities are positively and significantly associated with Tobin's Q and ROA consistent with prior studies (e.g. Jang \& Choi, 2010), whereas based on adjusted CSR score, the positive CSR-CFP relation becomes weaker or insignificant depending on sample periods. These results remain robust after various sensitivity tests. Accordingly, this result implies that the well-known positive CSR-CFP relationship in Korea setting might be exaggerated due to the potential measurement problem of CSR score.

This study primarily contributes to the literature on the relationship between CSR and CFP by providing the evidence that adjusted KEJI CSR score significantly weakens the positive relationship between unadjusted KEJI score and CFP documented in prior studies. Our evidence has an important implication to researchers in that we 
show the importance of adjusting the original CSR score to proxy for the proper level of CSR activities in Korea setting depending on the research question in the study. Since KEJI CSR score has many dimensions, it is crucial for the researcher to adjust the CSR score by excluding a specific component if that component is known to have a significant relationship with the variable of interest. For example, Yongtae Kim et al. (2012) show that governance components in KLD ratings should be excluded when studying the relationship between CSR and earnings management because governance is known to control a firm's earnings management. Similarly, Cho and Chun (2015) adjust KEJI CSR score by excluding governance components in the study on the relationship between CSR and real activities earnings management in Korea setting. We thus suggest that adjusted KEJI CSR score that excludes performance component needs to be employed in the future CSR study especially in studies dealing with CFP.

The remainder of this paper is organized as follows. Section II provides a literature review and research question. Section III describes sample data, research design, and measurements of variables. Section IV discusses the empirical results and the results of sensitivity tests. Section V summarizes and concludes the study.

\section{LITERATURE REVIEW AND RESEARCH QUESTION}

Figure 1 provides the research framework of this study. This study's primary objective is to examine whether the adjusted KEJI CSR score that excludes the performance component from the original CSR score weakens the positive relationship between CSR and performance using original KEJI CSR score in prior studies in Korea setting. The corporate financial performance is measured by TOBINQ and ROA.

Figure 1. Research Model

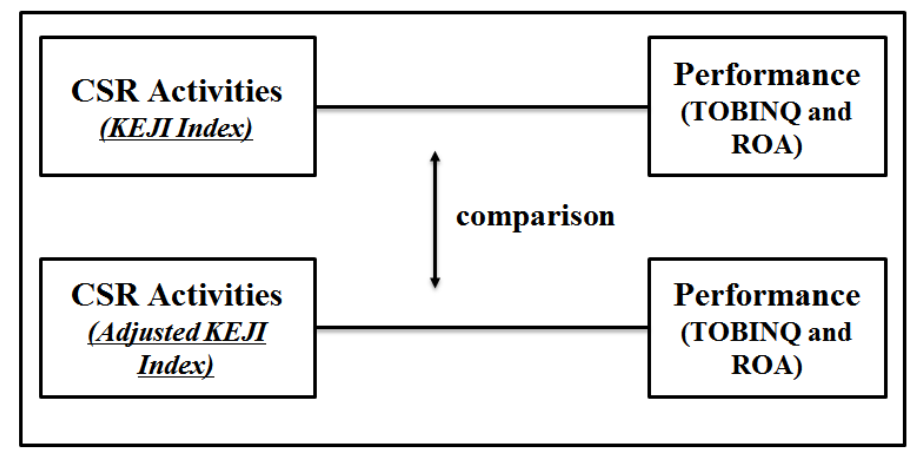

\section{The Relationship Between CSR and CFP}

Examining the relationship between CSR and CFP has been a lively topic since 1970s. There are various arguments in terms of the relationship between CSR and CFP. One view is based on shareholder theory proposed by Friedman (1970) which supports the argument that CSR activities can be costs and, thus, against shareholders' wealth. This argument is closely related to maximizing shareholder value. However, the contrasting view is based on stakeholder theory proposed by Freeman (1984), which supports the contention that CSR activities produce more benefits than costs through a good relationship with a firm's diverse stakeholders. ${ }^{\text {iv }}$

Although the relationship between CSR and CFP has been a lively addressed research topic since the 1970s (Beurden \& Gössling, 2008), researchers have not reached consensus on the relationship between two variables (Cochran \& Wood, 1984; Akpinar et al., 2008; Hull \& Rothenberg, 2008; Perrini et al., 2011; Aguinis \& Glavas, 2012). These studies imply that CSR activities may have a diverse effect on CFP. For example, Barnett (2007, p. 801) argues that equal CSR investment by different firms, or even the same firm at different points in time, does not produce equal amount of financial gain, as implied by thirty years of inconsistent findings.

Prior CSR studies in Korea on the relationship between CSR and CFP also show mixed results. Table 1 shows the summary of the prior studies' empirical results on the relationship between CSR and CFP in Korea setting. Three relationships (i.e. positive, negative, and neutral) between CSR and CFP exist even though majority 
studies document the positive relationship between CSR and CFP mainly measured by Tobin's Q and ROA (C. Kim, 2009; Heo \& Chung, 2010; Jang \& Choi, 2010; Y Kim \& Wee, 2011; Kook \& Kang, 2011; Na \& Hong, 2011). Specifically, several studies (C. Kim, 2009; Jang \& Choi, 2010; Kook \& Kang, 2011) document that the relationship between CSR and Tobin's Q is positive. Further, other studies (Jang \& Choi, 2010) report that the relationship between CSR and ROA is positive. In addition, we also observe that KEJI index is widely used to measure the level of CSR activities for Korean public firms.

In international setting, mainly the U.S settings, a number of researchers document the positive relationship between CSR and CFP (Bragdon Jr \& Marlin, 1972; Moskowitz, 1972; Spicer, 1978; McGuire et al., 1988; Waddock \& Graves, 1997; Dowell et al., 2000; Ruf et al., 2001; Schnietz \& Epstein, 2005). As well, Goll and Rasheed (2004) contend that the most recent developments in CSR studies show a more positive linkage between CSR and CFP than does earlier research. Positive relationship implies that the CSR costs incurred are small and the CSR benefits are large. In the review studies on the relationship between CSR and CFP, Peloza (2009) summarizes that $68 \%, 15 \%$, and $22 \%$ of 159 articles published for the year of $1972-2008$ report a positive, negative, and mixed relationship, respectively. Recently, using 588 journal articles and 102 books from 1970 to 2011, Aguinis and Glavas (2012) examine the relationship between CSR and CFP. The results show that there is a small, but a positive relationship between CSR activities and CFP. Meanwhile, Beurden and Gössling (2008) show 68\% of the positive relationship based on 34 studies.

Table 1. Summary of the Prior Empirical Studies on the Relationship between CSR and CFP

\begin{tabular}{|c|c|c|c|}
\hline Author (Year) & Sample firms (Sample period) & CSR measures & CFP Measures \\
\hline \multicolumn{4}{|c|}{ Positive relationship } \\
\hline C. $\operatorname{Kim}(2009)$ & KOSPI 1,116 firm-years (1999-2007) & $\begin{array}{l}\text { Sustainable management } \\
\text { index }\end{array}$ & Tobin's Q \\
\hline Heo and Chung (2010) & $\begin{array}{l}\text { KOSPI } 140 \text { firm-years (selected more } \\
\text { than } 3 \text { times in a row by KEJI and } \\
\text { selected for most admired firms in } \\
\text { Korea by KMAC)(2004-2008) } \\
\text { among upper } 200 \text { firms disclosed by } \\
\text { KEJI }\end{array}$ & KEJI Index & $\begin{array}{l}\text { Price to book value ratio } \\
\text { (PBR) }\end{array}$ \\
\hline Jang and Choi (2010) & $\begin{array}{l}\text { KOSPI } 130 \text { firms (selected more than } \\
5 \text { times in the upper } 200 \text { firms during } \\
8 \text { years of sample period) (1998- } \\
\text { 2005) among upper } 200 \text { firms } \\
\text { disclosed by KEJI }\end{array}$ & KEJI Index & $\begin{array}{l}\text { Return on assets (ROA, } \\
\text { EBIT/Total assets), } \\
\text { Tobin's Q }\end{array}$ \\
\hline Y Kim and Wee (2011) & $\begin{array}{l}\text { KOSPI 1,238 firm-years (2002-2008) } \\
\text { among upper } 200 \text { firms disclosed by } \\
\text { KEJI }\end{array}$ & KEJI Index & $\begin{array}{l}\text { Return on assets (ROA) } \\
\text { (Net income/Total } \\
\text { assets) }\end{array}$ \\
\hline Kook and Kang (2011) & KOSPI 503 firm-years (2008-2009) & KRX SRI Index & Tobin's Q \\
\hline $\mathrm{Na}$ and Hong (2011) & $\begin{array}{l}\text { KOSPI } 74 \text { firms (selected } 5 \text { times in } \\
\text { a row in the upper } 200 \text { firms) (2004- } \\
\text { 2008) among upper } 200 \text { firms } \\
\text { disclosed by KEJI }\end{array}$ & $\begin{array}{l}\text { KEJI Index (Employee } \\
\text { satisfaction and economic } \\
\text { development contribution } \\
\text { measures) }\end{array}$ & Tobin's Q \\
\hline \multicolumn{4}{|c|}{ Negative relationship } \\
\hline $\mathrm{Na}$ and Hong (2011) & $\begin{array}{l}\text { KOSPI } 74 \text { firms (selected } 5 \text { times in } \\
\text { a row in the upper } 200 \text { firms) (2004- } \\
\text { 2008) among upper } 200 \text { firms } \\
\text { disclosed by KEJI }\end{array}$ & $\begin{array}{l}\text { KEJI Index (Environmental } \\
\text { protection measure) }\end{array}$ & Tobin's Q \\
\hline \multicolumn{4}{|c|}{ Neutral relationship } \\
\hline J.-S. Choi et al. (2010) & $\begin{array}{l}\text { KOSPI 1,222 firm-years (2002-2008) } \\
\text { among upper } 200 \text { firms disclosed by } \\
\text { KEJI }\end{array}$ & KEJI Index & $\begin{array}{l}\text { Return on assets } \\
\text { (ROA, EBIT/Total } \\
\text { assets), Return on } \\
\text { equity (ROE), Tobin's } \\
\text { Q }\end{array}$ \\
\hline Y Kim and Wee (2011) & $\begin{array}{l}\text { KOSPI 1,238 firm-years (2002-2008) } \\
\text { among upper } 200 \text { firms disclosed by } \\
\text { KEJI }\end{array}$ & KEJI Index & Stock return \\
\hline
\end{tabular}




\section{Research Question}

Based on recent review studies for CSR research published during 1970s-2000s, several studies (Beurden \& Gössling, 2008; Peloza, 2009; Aguinis \& Glavas, 2012) document that the majority of prior studies support a positive relationship. Moreover, according to the studies using Korean firms' data shown in Table 2, the majority of studies also support a positive relationship using both Tobin's Q and ROA.

However, C. H. Kim et al. (2013, p. 2588) point out that Korean firms' CSR activities tend to be a short term version with public relations focus because CSR in Korea is mostly driven by government and societal regulative and normative pressures, implying that the relationship between CSR in Korea and CFP is not likely to be positive. Needless to say, CSR score as an independent variable of interest plays an important role in determining the relationship between CSR and CFP. Waddock and Graves (1997) point out CSR measurement problem as a reason for mixed results on the relationship between CSR and CFP. In Korea setting, although KEJI index is widely employed in CSR studies (J.-S. Choi et al., 2010; Heo \& Chung, 2010; Jang \& Choi, 2010; Y Kim \& Wee, 2011; Na \& Hong, 2011; Oh et al., 2011; B. B. Choi et al., 2013; H. Choi \& Moon, 2013), to our knowledge, to date there is no attempt to assess the measurement problem of KEJI index in the study on the relationship between CSR and CFP.

If there is a potential measurement problem in CSR score due to operating performance measures included in unadjusted CSR scores, the relationship between unadjusted CSR score and CFP is expected to be upward biased because of high correlation between operating performance measures and CFP. We predict that measurement problem of CSR score is likely to lead to the spurious positive results on CSR-CFP relationship in Korean setting. In this study, we assess the impact of the measurement problem of KEJI index on CFP by performing empirical analysis adjusted KEJI index obtained by excluding performance component from the original CSR index. Hence, we provide the following research question.

Research Question: Does adjusted KEJI CSR score weaken the positive relationship between CSR and CFP compared to unadjusted KEJI CSR score?

To test this research question, we use not only unadjusted CSR score but also adjusted CSR score. Further, Tobin's Q and ROA is used as CFP measures because Tobin's Q (C. Kim, 2009; Jang \& Choi, 2010; Kook \& Kang, 2011; Na \& Hong, 2011) and ROA (J.-S. Choi et al., 2010; Jang \& Choi, 2010) are widely used in the prior studies as shown in Table 1.

\section{RESEARCH DESIGN}

\section{Sample Data}

We employ KEJI CSR score to proxy for the level of firm's CSR activities. ${ }^{\mathrm{v}}$ The KEJI CSR scores(maximum total 75points) consists of seven categories of the KEJI Index measures: soundness (20 points), fairness (11 points), social contribution (7 points), customer protection and satisfaction (7 points), environmental protection activity (10 points), employee satisfaction (10 points), and economic development contribution (10 points) $)^{\mathrm{vi}}(\text { KEJI, 2011) })^{\text {vii }}$ (refer to Appendix B).

KEJI CSR scores appear to represent the level of firm's CSR activities objectively to some degree because the measurement methods are comparable to the KLD ratings (Oh et al., 2011). For other variables, we collect the data from KISVALUE, which is provided by NICE GROUP viii, one of the largest financial data providers in Korea, and widely used in the academic research. Data availability restricts the sample to 1,301 firm-year observations of the listed Korean firms.

\section{Research Design}

In order to capture the relationship between the level of CSR activities measured by KEJI index (i.e. adjusted and unadjusted CSR score) and CFP measured by Tobin's Q and ROA, we estimate the following 
multivariate regression Equations (1) and (2). $A D J$ ROA variable is omitted in Equation (2) because $R O A$ and $A D J R O A$ are highly correlated.

$$
\begin{aligned}
& T_{O B I N Q_{i . t}}=\alpha_{0}+\alpha_{1} \text { CSR }_{i, t}\left(\text { or ADJ_CSR } R_{i, t}\right)+\alpha_{2} \operatorname{SIZE}_{i, t}+\alpha_{3} \text { LEVERAGE }_{i, t} \\
& +\alpha_{4} A D J R O A_{i, t}+\alpha_{5} R_{L} I S K_{i, t}+\alpha_{6} \text { GOVERN }_{i, t} \\
& +\alpha_{7} F I R \bar{M}_{-} A G E_{i, t}+\sum I N D+\sum Y E A R+\varepsilon_{i, t} \ldots \ldots \ldots \\
& R O A_{i . t}=\alpha_{0}+\alpha_{1} \text { CSR }_{i, t}\left(\text { or ADJ_CSR } i_{i, t}\right)+\alpha_{2} \operatorname{SIZE}_{i, t}+\alpha_{3} \operatorname{LEVERAGE}_{i, t} \\
& +\alpha_{4} R I S \bar{K}_{i, t}+\alpha_{5} \text { GOVERN }_{i, t}+\alpha_{6} \text { FIRM_AGE } E_{i, t} \\
& +\sum I N D+\sum Y E A R+\varepsilon_{i, t} \ldots \ldots \ldots
\end{aligned}
$$

where, for company $i$ in period $t$ :

\begin{tabular}{ll}
\hline TOBINQ & \multicolumn{1}{c}{ Dependent Variables } \\
ROA & (market value of common and preferred stock + long term liabilities) / book value of total assets, at fiscal \\
& year-end in period $t$; and
\end{tabular}

\section{Measurement of Variables}

Although prior studies employ unadjusted CSR scores to measure a firm's CSR activities, we additionally use adjusted CSR scores for the following reasons. Unadjusted CSR score contains operating performance related measures (i.e. economic development contribution). If operating performance measures are included, they may cause to result in upward bias for the relationship between CSR and CFP because economic development contribution measure is highly and positively correlated with CFP as shown in Table 2 below $(0.37, \mathrm{p}<0.01$ with TOBINQ; $0.23, \mathrm{p}<0.01$ with $R O A$ ). Thus, we exclude operating performance measures (i.e. economic development contribution) from the original unadjusted CSR scores to measure adjusted CSR scores. Tobin's Q is measured using market value of equity plus liabilities divided by book value total assets. ROA is operating income divided by total assets as of fiscal year end.

Table 2. Correlation Coefficients between ECONO_CONT and TOBINQ and ROA

\begin{tabular}{lccc}
\hline & ECONO_CONT & TOBINQ & ROA \\
\hline ECONO_CONT & 1 & & \\
TOBINQ & $0.37^{* *}$ & 1 & 1 \\
ROA & $0.23^{* *}$ & $0.42^{* *}$ & 1,301 \\
$\mathrm{n}$ & 1,301 & 1,301 & \\
\hline
\end{tabular}

Pearson correlation coefficients are shown below the diagonal. * and ** indicate statistical significance at the 5 percent and 1 percent levels on a two-tailed test, respectively. Variables are defined in Appendix A.

In order to avoid the problems of correlated omitted variables related to the firm's financial performance, we include control variables that may affect the relationship between CSR and CFP. First, firm size (SIZE) is widely 
used in empirical research as a control variable (Waddock \& Graves, 1997; Shin \& Stulz, 1998; Seifert et al., 2004). Arlow and Gannon (1982) suggest that based on the review of several prior studies, organization size is an important factor in CSR studies. Black et al. (2006) and Demsetz and Lehn (1985) argue that firm size is negatively related to the financial performance. However, if economy of scale exists, a large firm is positively associated with financial performance because it has bargaining power against suppliers and buyers (Porter, 1985). Moreover, a large firm tends to disclose much information about itself, leading to decreasing information uncertainty about itself and increasing firm value (C. Kim, 2009; Kook \& Kang, 2011). Prior studies (Stanwick \& Stanwick, 1998; Moore, 2001) find a significant positive relationship between firm size and CFP. In this study, given that sample firms are listed firms that have relatively large size and are likely to realize the economy of scale and disclose much information, we predict that firm size is positively associated with financial performance.

Second, financial leverage ( $L E V E R A G E$ ) equals total liabilities divided by total assets as of fiscal year end. Financial leverage affects a firm's value such as Tobin's Q (De, 1992; Waddock \& Graves, 1997). If a firm's leverage is high, it is highly likely to face financial difficulties. This financial risk may lead to higher financing costs, thereby resulting in negative association with the firm value. However, if a firm's leverage is not high, interest expense contributes to decreasing its financing costs because of tax deduction effects on interest payment, thereby resulting in a higher financial performance. Thus, given that this study's sample observations are listed and low leverage firms, we predict a positive sign of the coefficient. In contrast, with respect to $R O A$, if financial leverage ratios are high, a firm has to pay more interests that are directly deducted from earnings than a low financial leverage firm. Thus, a negative relationship between $R O A$ and $L E V E R A G E$ is expected.

Third, industry mean adjusted profitability $(A D J R O A)$ is included to control for a firm's profitability (McGuire et al., 1988; Seifert et al., 2004). A firm's profitability is expected to positively affect Tobin's Q. Hence, the predicted sign of the coefficient is positive.

Fourth, business risk (RISK) is used to control for the firm's risk (McGuire et al., 1988; Kook \& Kang, 2011 ) and measured by the standard deviation of prior 5 years EBITDA ${ }^{\text {ix }}$ divided by total assets. We expect that risk can be positively associated with Tobin's Q and ROA. One of the possible explanations is that high earnings volatility or high risk can be related to high returns. Hence, we predict the sign of coefficient of the RISK variable is positive.

Fifth, corporate governance (GOVERN) is employed to control for the firm's level of governance system and measured by the natural log of comprehensive governance score provided by Korea Corporate Governance Service. Corporate governance in Korea is considered to be important and likely to affect on the market value of the Korean listed firms (Black et al., 2006). Several corporate governance measures are also used in the study of the relationship between CSR and firm value as a control variable for the Korean public companies (C. Kim, 2009). Based on the review study on corporate governance with emphasis on emerging markets, Claessens and Yurtoglu (2013) report that better corporate governance such as ownership structures to protect outside investors and less deviation between cash flow and voting rights benefit firms through better performance and lower cost of capital. Bhagat and Bolton (2008) show governance is significant and positively correlated with operating performance. Thus, the expected sign of the coefficients of GOVERN is positive.

Sixth, firm age (FIRM_AGE) is also used in studies on firm valuation (Drobetz et al., 2004; Black et al., 2006; C. Kim, 2009). Old firms are likely to be in a mature industry, leading to restriction of their growth potential and lower Tobin's Q (Black et al., 2006). In other words, growing young firms tend to invest in intangible assets such as R\&D and realize quick growth rate. Given that stock price is the function of growth rate, firm age thus is expected to be negatively associated with Tobin's Q (Kook \& Kang, 2011). We predict that firm age has a negative relationship with CFP.

Seventh, we include industry dummy variables to control for industry effects and use KSIC (Korea Standard Industry Classification) two-digit industry codes (Waddock \& Graves, 1997; Strike et al., 2006; Kook \& Kang, 2011). Arlow and Gannon (1982) suggest that industry characteristics are an important factor in the study on CSR-CFP. Lastly, we also include five dummy variables for years to control for changes in economic conditions during the six years of this study (Lien \& $\mathrm{Li}, 2013$ ). 


\section{EMPIRICAL RESULTS}

\section{Descriptive Statistics and Univariate Analysis}

Table 3 provides the descriptive statistics of selected variables. In Table 3, Panel A presents the descriptive statistics of unadjusted CSR scores for each year over the sample period which shows a pretty even distribution. The mean value ranges from 45.03 to 45.75 over the sample period of 2005-2010. The mean of minimum (maximum) value of CSR score is 35.80 (57.15), whose difference is 21.35. Moreover, the descriptive statistics of adjusted CSR scores also show a pretty even distribution. The mean value ranges from 40.39 to 40.89 . The mean of minimum (maximum) value of CSR score is 31.53 (51.28), whose difference is 19.75 .

Panel B of Table 3 reports the descriptive statistics of selected variables in the full sample. The mean value of CSR (ADJ_CSR) is 3.815(3.702), which is calculated by natural log of unadjusted CSR score (adjusted CSR score). All continuous variables except the CSR variable are winsorized at the $1^{\text {st }}$ and $99^{\text {th }}$ percentiles to mitigate the problem of outliers. ${ }^{\mathrm{x}}$ The mean value of Tobin's $\mathrm{Q}(T O B I N Q)$ is 1.005 . The mean value of operating return on asset $(R O A)$ is 6.6 percent, implying that sample firms appear to be profitable in the industry. Given that sample firms are listed firms in Korea Stock Exchange market, this result is consistent with our expectation.

For the control variables, the mean value of SIZE is 26.415 , i.e. US\$296 million converted using exchange rate of 1,000 Korean won per US 1 dollar, indicating the full sample consists of large firms in Korea due to the fact that KEJI offers CSR scores for selective KOSPI (Korea Composite Stock Price Index) firms. The mean values of financial leverage (LEVERAGE), adjusted return on asset (ADJ_ROA), and earnings volatility (RISK), and governance level $(G O V E R N)$ are 38.9 percent, 0.00 percent, 3.1 percent, and 4.695, respectively, indicating that sample firms seem to have a stable capital structure and low level of risk.

Turning to the Pearson's correlation coefficients for selected variables, TOBINQ and ROA are significant and positively correlated with CSR(ADJ_CSR) $(0.32(0.26)$ and $0.25(0.22), \mathrm{p}<0.01), \operatorname{SIZE}(0.29$ and $0.13, \mathrm{p}<0.01)$, and GOVERN (0.37 and 0.21, $<<0.01)$, observing that correlation between ADJ_CSR and CFP is lower than that between CSR and CFP as expected. We observe that the correlation coefficients between SIZE and GOVERN are $0.60(\mathrm{p}<0.01)$, slightly higher than 0.50 , which might cause multicollinearity. We check multicollinearity of independent variables in the regression models using variation inflation factors (VIF) and do not find material multicollinearity problem in the sample. We observe that the correlation coefficient between ROA and ADJROA is $0.65(\mathrm{p}<0.01)$, which is highly correlated. We omit the $A D J \_R O A$ in the regression model when using $R O A$ as a dependent variable.

Table 3. Descriptive Statistics of Selected Variables

Panel A: Descriptive Statistics of Unadjusted and Adjusted CSR Score

\begin{tabular}{|c|c|c|c|c|c|c|c|c|}
\hline \multicolumn{9}{|c|}{ Unadjusted CSR Score } \\
\hline Year & $\mathbf{n}$ & Mean & Median & Std. Dev. & Min. & $\begin{array}{c}\text { 25th } \\
\text { Percentile }\end{array}$ & $\begin{array}{c}\text { 75th } \\
\text { Percentile }\end{array}$ & Max. \\
\hline 2005 & 230 & 45.34 & 45.60 & 3.39 & 36.67 & 43.20 & 47.31 & 55.82 \\
\hline 2006 & 199 & 45.62 & 45.71 & 3.45 & 37.03 & 43.21 & 48.12 & 56.33 \\
\hline 2007 & 208 & 45.03 & 44.81 & 3.62 & 35.87 & 42.61 & 47.41 & 57.15 \\
\hline 2008 & 200 & 45.57 & 45.35 & 3.88 & 36.63 & 42.86 & 48.51 & 56.39 \\
\hline 2009 & 216 & 45.70 & 45.54 & 3.79 & 35.80 & 42.98 & 48.68 & 55.51 \\
\hline 2010 & 248 & 45.75 & 45.67 & 3.39 & 38.00 & 43.29 & 48.04 & 56.26 \\
\hline Total & 1301 & 45.51 & 45.42 & 3.58 & 35.80 & 43.05 & 48.03 & 57.15 \\
\hline \multicolumn{9}{|c|}{ Adjusted CSR Score } \\
\hline Year & $\mathbf{n}$ & Mean & Median & Std. Dev. & Min. & $\begin{array}{c}\text { 25th } \\
\text { Percentile }\end{array}$ & $\begin{array}{c}\text { 75th } \\
\text { Percentile }\end{array}$ & Max. \\
\hline 2005 & 230 & 40.39 & 40.58 & 3.11 & 31.82 & 38.57 & 42.22 & 49.40 \\
\hline 2006 & 199 & 40.58 & 40.62 & 3.14 & 31.68 & 38.56 & 42.85 & 50.06 \\
\hline 2007 & 208 & 40.60 & 40.48 & 3.27 & 31.56 & 38.53 & 42.75 & 51.28 \\
\hline 2008 & 200 & 40.60 & 40.65 & 3.48 & 32.28 & 38.13 & 43.10 & 49.95 \\
\hline 2009 & 216 & 40.76 & 40.44 & 3.42 & 31.53 & 38.57 & 43.35 & 49.34 \\
\hline 2010 & 248 & 40.89 & 40.69 & 3.09 & 33.03 & 38.67 & 42.82 & 49.87 \\
\hline Total & 1301 & 40.64 & 40.58 & 3.25 & 31.53 & 38.54 & 42.76 & 51.28 \\
\hline
\end{tabular}


(Table 3 continued)

Panel B. Mean, Standard Deviation, and Correlation Coefficients

\begin{tabular}{|c|c|c|c|c|c|c|c|c|c|}
\hline & Variable & Mean & S.D. & 1 & 2 & 3 & 4 & 5 & 6 \\
\hline 1. & TOBINQ & 1.005 & 0.447 & 1 & & & & & \\
\hline 2. & $R O A$ & 0.066 & 0.055 & $0.42 * *$ & 1 & & & & \\
\hline 3. & $C S R$ & 3.815 & 0.079 & $0.32 * *$ & $0.25 * *$ & 1 & & & \\
\hline 4. & $A D J \_C S R$ & 3.702 & 0.080 & $0.26 * *$ & $0.22 * *$ & $0.98 * *$ & 1 & & \\
\hline 5. & $S I Z E$ & 26.415 & 1.332 & $0.29 * *$ & $0.13 * *$ & $0.44 * *$ & $0.40 * *$ & 1 & \\
\hline 6. & LEVERAGE & 0.389 & 0.168 & $0.18^{* *}$ & $-0.09 * *$ & $-0.23 * *$ & $-0.25^{* *}$ & $0.20 * *$ & 1 \\
\hline 7. & $A D J \_R O A$ & 0.000 & 0.057 & $0.25^{* *}$ & $0.65 * *$ & $0.14^{* *}$ & $0.12 * *$ & $0.11 * *$ & $-0.29 * *$ \\
\hline 8. & RISK & 0.031 & 0.019 & $0.06^{*}$ & $0.13 * *$ & $-0.12 * *$ & $-0.11 * *$ & $-0.17 * *$ & 0.03 \\
\hline 9. & GOVERN & 4.695 & 0.197 & $0.37 * *$ & $0.21 * *$ & $0.53 * *$ & $0.49 * *$ & $0.60 * *$ & $0.05 *$ \\
\hline \multirow[t]{3}{*}{10.} & $F I R M \_A G E$ & 3.538 & 0.508 & $-0.22 * *$ & $-0.08 * *$ & -0.01 & 0.01 & 0.03 & $-0.11 * *$ \\
\hline & $\mathrm{n}$ & 1301 & 1301 & 1301 & 1301 & 1301 & 1301 & 1301 & 1301 \\
\hline & Variable & Mean & S.D. & 7 & 8 & 9 & 10 & & \\
\hline 7. & $A D J \_R O A$ & 0.000 & 0.057 & 1 & & & & & \\
\hline 8. & RISK & 0.031 & 0.019 & -0.04 & 1 & & & & \\
\hline 9. & GOVERN & 4.695 & 0.197 & 0.05 & $-0.15^{* *}$ & 1 & & & \\
\hline \multirow[t]{2}{*}{10.} & $F I R M \_A G E$ & 3.538 & 0.508 & -0.03 & $-0.10 * *$ & $-0.06^{*}$ & 1 & & \\
\hline & $\mathrm{n}$ & 1301 & 1301 & 1301 & 1301 & 1301 & 1301 & & \\
\hline
\end{tabular}

Pearson correlation coefficients are shown below the diagonal. ${ }^{*}$ and $* *$ indicate statistical significance at the 5 percent and 1 percent levels on a two-tailed test, respectively. Variables are defined in Appendix A.

\section{Regression Analysis}

We use beta coefficients (standardized coefficients) to show the results of the multivariate regressions in Table 4. Beta coefficients are known to help researchers interpret the extent of relative effects of independent variables on the dependent variable. We also calculate robust standard errors to control the heteroskedasticity problems that occur in our pooled OLS regression models.

Models 1 and 2 of Table 4 show the results of the multivariate regression analyses. The dependent variable employed to measure financial performance is TOBINQ. The independent variables of interest are CSR and $A D J C S R$, respectively, which represent the level of CSR activities. The result of Model 1 in Table 4 shows that the estimated coefficient of CSR is positive and significant $(0.098, \mathrm{p}<0.01)$, whereas Model 2 of Table 4 presents that $A D J \_C S R$ is positive and significant $(0.063, \mathrm{p}<0.05)$, implying that beta coefficient decreases together with the lower statistical significance level when $A D J C S R$ is used. The result of Model 1 is consistent with prior studies (C. Kim, 2009; Jang \& Choi, 2010; Kook \& Kang, 2011) using unadjusted CSR scores in Korea setting.

Turning to the control variables, in Model 1 of Table $4,{ }^{\mathrm{xi}}$ all of the coefficients for the SIZE, LEVERAGE, $A D J \_R O A, R I S K$, and GOVERN variables are significantly positive $(\mathrm{p}<0.01)$ as expected. These results indicate that larger firms, firms with higher leverage ratios, profitable firms, and firms with better corporate governance appear to have a positive effect on TOBINQ. Further, as expected, FIRM_AGE is significant and negatively related to $T O B I N Q$. This implies that as firms get older or reach a mature stage of firm's life cycle, they tend to negatively affect $T O B I N Q$. The adjusted $\mathrm{R}^{2}$ is 0.42 for both models 1 and 2 , showing reasonable explanatory powers to test our research question.

Models 3 and 4 of Table 4 report the results of the regression analyses when the dependent variable used to measure financial performance is $R O A$. Model 3 of Table 4 shows that the coefficient $(0.079, \mathrm{p}<0.05)$ of $C S R$ is significantly positive with ROA, which is consistent with prior study (Jang \& Choi, 2010) using unadjusted CSR scores in Korea. However, CSR is insignificantly related to ROA in other study(J.-S. Choi et al., 2010) probably because of different sample period and sample selection. ${ }^{\text {xii }}$ However, in Model 4 of Table 4 the coefficient of 
ADJ_CSR is positive but insignificant $(0.040, \mathrm{t}: 1.08)$, implying that CSR activities are not related to firm's accounting performance measure (ROA) when $A D J_{-} C S R$ is used to measure the level of a firm's CSR activities.

Regarding the control variables, in Model 3 of Table 4, direction and significance of the control variables except LEVERAGE are similar to the results of Model 1 of Table 4 as discussed above. We discuss LEVERAGE variable. One possible reason why the direction of $L E V E R A G E$ is negative (coefficient: $-0.071, \mathrm{p}<0.05$ ) is that if a firm's operating performance is poor, it needs to borrow debts to do investing activities such as purchasing fixed assets. Conversely, if a firm's operating performance is good, it is likely to repay debts because it has adequate fund to invest into buying fixed assets. The adjusted $\mathrm{R}^{2}$ values in the models are 0.20 , showing reasonable explanatory power of the regression models to test our research question.

Table 4. Regressions of Financial Performance on Unadjusted \& Adjusted CSR SCORE

\begin{tabular}{|c|c|c|c|c|c|c|}
\hline \multicolumn{7}{|c|}{ (Sample Period: 2005-2010) } \\
\hline & & Model 1 & Model 2 & & Model 3 & Model 4 \\
\hline & & \multicolumn{5}{|c|}{ Dependent variables } \\
\hline & & TOBINQ & TOBINQ & & $R O A$ & $R O A$ \\
\hline Independent variables & Sign & $\begin{array}{c}\text { Coefficient } \\
\text { (t-stat) }\end{array}$ & $\begin{array}{c}\text { Coefficient } \\
\text { (t-stat) }\end{array}$ & Sign & $\begin{array}{c}\text { Coefficient } \\
\text { (t-stat) }\end{array}$ & $\begin{array}{c}\text { Coefficient } \\
\text { (t-stat) }\end{array}$ \\
\hline$C S R$ & + & $\begin{array}{c}0.098^{* * * *} \\
(3.12) \\
\end{array}$ & & + & $\begin{array}{c}0.079 * * \\
(2.02) \\
\end{array}$ & \\
\hline$A D J \_C S R$ & + & & $\begin{array}{c}0.063 * * \\
(2.09) \\
\end{array}$ & + & & $\begin{array}{c}0.040 \\
(1.08) \\
\end{array}$ \\
\hline SIZE & + & $\begin{array}{c}0.120^{* * *} * \\
(3.91)\end{array}$ & $\begin{array}{c}0.134 * * * \\
(4.44)\end{array}$ & + & $\begin{array}{c}0.101 * * * \\
(2.59)\end{array}$ & $\begin{array}{c}0.115 * * * \\
(3.01)\end{array}$ \\
\hline LEVERAGE & + & $\begin{array}{c}0.302 * * * \\
(12.72)\end{array}$ & $\begin{array}{c}0.294 * * * \\
(12.26)\end{array}$ & - & $\begin{array}{c}-0.071 * * \\
(-2.48)\end{array}$ & $\begin{array}{c}-0.080 * * * \\
(-2.83)\end{array}$ \\
\hline$A D J \_R O A$ & + & $\begin{array}{c}0.280^{* * * *} \\
(9.42)\end{array}$ & $\begin{array}{c}0.282 * * * \\
(9.45)\end{array}$ & & & \\
\hline RISK & + & $\begin{array}{c}0.094 * * * \\
(3.71)\end{array}$ & $\begin{array}{c}0.094 * * * \\
(3.68)\end{array}$ & + & $\begin{array}{c}0.122 * * * \\
(2.95)\end{array}$ & $\begin{array}{c}0.122 * * * \\
(2.93)\end{array}$ \\
\hline GOVERN & + & $\begin{array}{c}0.153 * * * \\
(4.92)\end{array}$ & $\begin{array}{c}0.164 * * * \\
(5.25)\end{array}$ & + & $\begin{array}{l}0.057 \\
(1.47)\end{array}$ & $\begin{array}{c}0.068^{*} \\
(1.76)\end{array}$ \\
\hline FIRM_AGE & - & $\begin{array}{c}-0.172 * * * \\
(-5.49)\end{array}$ & $\begin{array}{c}-0.174 * * * \\
(-5.49)\end{array}$ & - & $\begin{array}{c}-0.084 * * * \\
(-2.84)\end{array}$ & $\begin{array}{c}-0.086^{* * *} \\
(-2.90)\end{array}$ \\
\hline $\begin{array}{l}\text { Industry dummies } \\
\text { Year dummies }\end{array}$ & & $\begin{array}{l}\text { Included } \\
\text { Included }\end{array}$ & $\begin{array}{l}\text { Included } \\
\text { Included }\end{array}$ & & $\begin{array}{l}\text { Included } \\
\text { Included }\end{array}$ & $\begin{array}{l}\text { Included } \\
\text { Included }\end{array}$ \\
\hline $\begin{array}{l}\text { Mean of VIF } \\
\text { Adj. } R^{2} \\
\text { F } \\
\text { n }\end{array}$ & & $\begin{array}{c}1.58 \\
0.42 \\
34.55^{* * *} \\
1301\end{array}$ & $\begin{array}{c}1.58 \\
0.42 \\
33.93 * * * \\
1301\end{array}$ & & $\begin{array}{c}1.57 \\
0.20 \\
24.44 * * * \\
1301\end{array}$ & $\begin{array}{c}1.57 \\
0.20 \\
24.54 * * * \\
1301\end{array}$ \\
\hline
\end{tabular}

In sum, these results above in Table 4 support that among the seven individual components of KEJI CSR scores, the economic development contribution category plays an important role in contributing to the positive relationship with CFP because it is related to operating performance measures. These results suggest that researchers consider the importance of excluding the economic development contribution category from KEJI CSR scores (i.e., adjusted CSR scores) to prevent observing the spurious relationship between CSR and CFP.

\section{Sensitivity Tests}

In Table 4, we show the results that the relationships between CSR activities and CFP measured by Tobin's Q and ROA are affected, depending on which CSR measures such as unadjusted and adjusted CSR score are used. Specifically, the positive relationship between CSR and CFP using unadjusted CSR score weakens compared to the adjusted CSR score. To secure robustness of our results, using the disclosed and undisclosed CSR score ${ }^{\text {xiii }}$ to the public, we perform sensitivity tests by running regression analyses using different sample periods, 2005-2009 
and 2005-2008, respectively. In addition, given that prior studies are mostly performed using the sample data of the disclosed CSR score to the public, regression analyses using the disclosed CSR score to the public are performed to compare with prior studies and confirm whether or not the our conclusion remains unchanged.

\section{Full Sample Data of Disclosed and Undisclosed CSR Score}

Using the period of 2005-2009 data, the result of Model 1 in Table 5 shows that the estimated coefficient of $C S R$ is positive and significant $(0.105, \mathrm{p}<0.01)$ in explaining $T O B I N Q$ consistent with the results of prior studies, whereas Model 2 of Table 5 presents that $A D J C S R$ is positive and marginally significant $(0.067, \mathrm{p}<0.10)$, implying that beta coefficient decreases together with the lower statistical significance level when ADJ_CSR is used as an independent variable and TOBINQ is used as the dependent variable for CFP. Models 3 and 4 of Table 5 use $\boldsymbol{R O A}$ as dependent variable. The result shows that the coefficient $(0.094, \mathrm{p}<0.05)$ of $C S R$ is significantly positive with $R O A$ consistent with the results of prior studies, whereas Model 4 of Table 5 presents that coefficient of $A D J C S R$ is positive but insignificant $(0.044, \mathrm{t}: 1.04)$, implying that CSR activities are not related to ROA when ADJ_CSR is used to measure the level of CSR activities.

Table 5. Regressions of Financial Performance on Unadjusted \& Adjusted CSR SCORE

(Sample Period: 2005-2009)

\begin{tabular}{|c|c|c|c|c|c|c|}
\hline \multirow[b]{3}{*}{ Independent variables } & \multirow[b]{3}{*}{ Sign } & \multicolumn{5}{|c|}{ Dependent variables } \\
\hline & & \multirow{2}{*}{$\begin{array}{c}\text { Model 1 } \\
\text { TOBINQ } \\
\text { Coefficient } \\
\text { (t-stat) }\end{array}$} & \multicolumn{2}{|c|}{$\begin{array}{l}\text { Model } 2 \\
\text { TOBINQ }\end{array}$} & \multirow{2}{*}{$\begin{array}{c}\text { Model 3 } \\
\text { ROA } \\
\text { Coefficient } \\
\text { (t-stat) }\end{array}$} & \multirow{2}{*}{$\begin{array}{c}\text { Model } 4 \\
\text { ROA } \\
\text { Coefficient } \\
\text { (t-stat) } \\
\end{array}$} \\
\hline & & & $\begin{array}{c}\text { Coefficient } \\
\text { (t-stat) }\end{array}$ & Sign & & \\
\hline CSR & + & $\begin{array}{l}0.105^{* * *} \\
(2.91)\end{array}$ & & + & $\begin{array}{l}0.094 * * \\
(2.10)\end{array}$ & \\
\hline ADJ_CSR & + & & $\begin{array}{l}0.067 * \\
(1.94) \\
\end{array}$ & + & & $\begin{array}{c}0.044 \\
(1.04) \\
\end{array}$ \\
\hline SIZE & + & $\begin{array}{l}0.128^{* * *} \\
(3.73)\end{array}$ & $\begin{array}{l}0.143 * * * \\
(4.27)\end{array}$ & + & $\begin{array}{l}0.075^{*} \\
(1.75) \\
\end{array}$ & $\begin{array}{l}0.094 * * \\
(2.24) \\
\end{array}$ \\
\hline LEVERAGE & + & $\begin{array}{l}0.283^{* * *} \\
(10.54)\end{array}$ & $\begin{array}{l}0.274 * * * \\
(10.09)\end{array}$ & - & $\begin{array}{c}-0.051 \\
(-1.64)\end{array}$ & $\begin{array}{l}-0.064^{* *} \\
(-2.04)\end{array}$ \\
\hline$A D J \_R O A$ & + & $\begin{array}{l}0.264^{* * *} \\
(7.88)\end{array}$ & $\begin{array}{l}0.266^{* * *} \\
(7.92)\end{array}$ & & & \\
\hline RISK & + & $\begin{array}{l}0.077 * * * \\
(2.73)\end{array}$ & $\begin{array}{l}0.077 * * * \\
(2.74)\end{array}$ & + & $\begin{array}{l}0.098^{* *} \\
(2.11) \\
\end{array}$ & $\begin{array}{l}0.099 * * \\
(2.12) \\
\end{array}$ \\
\hline GOVERN & + & $\begin{array}{l}0.130^{* * *} \\
(3.69)\end{array}$ & $\begin{array}{l}0.141^{* * *} \\
(4.00)\end{array}$ & + & $\begin{array}{r}0.049 \\
(1.10) \\
\end{array}$ & $\begin{array}{r}0.062 \\
(1.42) \\
\end{array}$ \\
\hline FIRM_AGE & - & $\begin{array}{l}-0.182 * * * \\
(-5.23)\end{array}$ & $\begin{array}{l}-0.185 * * * \\
(-5.25)\end{array}$ & - & $\begin{array}{l}-0.096 * * * \\
(-2.99)\end{array}$ & $\begin{array}{l}-0.099 * * * \\
(-3.07)\end{array}$ \\
\hline $\begin{array}{l}\text { Industry dummies } \\
\text { Year dummies }\end{array}$ & & $\begin{array}{l}\text { Included } \\
\text { Included }\end{array}$ & $\begin{array}{l}\text { Included } \\
\text { Included }\end{array}$ & & $\begin{array}{l}\text { Included } \\
\text { Included }\end{array}$ & $\begin{array}{l}\text { Included } \\
\text { Included }\end{array}$ \\
\hline $\begin{array}{l}\text { Mean of VIF } \\
\text { Adj. } R^{2} \\
\text { F } \\
n\end{array}$ & 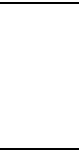 & $\begin{array}{c}1.58 \\
0.42 \\
23.99 * * * \\
1053 \\
\end{array}$ & $\begin{array}{l}1.58 \\
0.42 \\
23.71 * * * \\
1053 \\
\end{array}$ & & $\begin{array}{l}1.57 \\
0.21 \\
9.82 * * * \\
1053 \\
\end{array}$ & $\begin{array}{l}1.57 \\
0.21 \\
9.65 * * * \\
1053 \\
\end{array}$ \\
\hline
\end{tabular}

Using the period of 2005-2008 data, the result of Model 1 of Table 6 reports that the coefficient of CSR is positive and marginally significant $(0.073, \mathrm{p}<0.10)$, whereas Model 2 of Table 6 presents that $A D J C S R$ is positive but insignificant $(0.040, \mathrm{t}: 1.02)$, implying that CSR activities measured by $A D J C S R$ are not significantly related to Tobin's Q. Model 3 of Table 6 shows that the coefficient $(0.121, \mathrm{p}<0.05)$ of $C S \bar{R}$ is significantly positive with $R O A$, whereas Model 4 of Table 6 presents that coefficient of $A D J C C S R$ is positive but insignificant (0.063, t: 1.34), suggesting that CSR activities (ADJ_CSR) are not related to ROA. 
In sum, we confirm that the results using the sample data of disclosed and undisclosed CSR score to the public are consistent with prior studies using unadjusted CSR score. We also report that the relationship between CSR and CFP significantly weakens when ADJ_CSR is used.

Table 6. Regressions of Financial Performance on Unadjusted \& Adjusted CSR SCORE

(Sample Period: 2005-2008)

\begin{tabular}{|c|c|c|c|c|c|c|}
\hline & & \multicolumn{5}{|c|}{ Dependent variables } \\
\hline & & $\begin{array}{l}\text { Model } 1 \\
\text { TOBINQ } \\
\end{array}$ & $\begin{array}{l}\text { Model 2 } \\
\text { TOBINQ } \\
\end{array}$ & & $\begin{array}{c}\text { Model } 3 \\
\text { ROA } \\
\end{array}$ & $\begin{array}{c}\text { Model } 4 \\
\text { ROA }\end{array}$ \\
\hline Independent variables & Sign & $\begin{array}{c}\text { Coefficient } \\
\text { (t-stat) }\end{array}$ & $\begin{array}{c}\text { Coefficient } \\
\text { (t-stat) }\end{array}$ & Sign & $\begin{array}{c}\text { Coefficient } \\
\text { (t-stat) }\end{array}$ & $\begin{array}{c}\text { Coefficient } \\
\text { (t-stat) }\end{array}$ \\
\hline$C S R$ & + & $\begin{array}{c}0.073^{*} \\
(1.79) \\
\end{array}$ & & + & $\begin{array}{l}0.121^{* *} \\
(2.44)\end{array}$ & \\
\hline$A D J \_C S R$ & + & & $\begin{array}{r}0.040 \\
(1.02) \\
\end{array}$ & + & & $\begin{array}{l}0.063 \\
(1.34)\end{array}$ \\
\hline SIZE & + & $\begin{array}{l}0.130^{* * * *} \\
(3.52)\end{array}$ & $\begin{array}{l}0.143^{* * *} \\
(3.95)\end{array}$ & + & $\begin{array}{l}0.096^{* *} \\
(2.01)\end{array}$ & $\begin{array}{l}0.118^{* *} \\
(2.53)\end{array}$ \\
\hline LEVERAGE & + & $\begin{array}{l}0.285^{* * *} \\
(9.47)\end{array}$ & $\begin{array}{l}0.278^{* * *} \\
(9.07)\end{array}$ & - & $\begin{array}{r}-0.039 \\
(-1.06) \\
\end{array}$ & $\begin{array}{r}-0.054 \\
(-1.45) \\
\end{array}$ \\
\hline$A D J \_R O A$ & + & $\begin{array}{l}0.262^{* * *} \\
(6.93)\end{array}$ & $\begin{array}{l}0.264 * * * \\
(6.93)\end{array}$ & & & \\
\hline RISK & + & $\begin{array}{l}0.060^{* *} \\
(2.03)\end{array}$ & $\begin{array}{l}0.061^{* *} \\
(2.06)\end{array}$ & + & $\begin{array}{l}0.112 * * \\
(2.21)\end{array}$ & $\begin{array}{l}0.114 * * \\
(2.23)\end{array}$ \\
\hline GOVERN & + & $\begin{array}{l}0.117^{* * *} \\
(3.00)\end{array}$ & $\begin{array}{l}0.127 * * * \\
(3.26)\end{array}$ & + & $\begin{array}{r}0.012 \\
(0.24) \\
\end{array}$ & $\begin{array}{c}0.030 \\
(0.58) \\
\end{array}$ \\
\hline$\overline{F I R M \_A G E}$ & - & $\begin{array}{l}-0.187 * * * \\
(-4.85) \\
\end{array}$ & $\begin{array}{l}-0.190 * * * \\
(-4.88)\end{array}$ & - & $\begin{array}{l}-0.083^{* *} \\
(-2.32) \\
\end{array}$ & $\begin{array}{l}-0.087 * * \\
(-2.44) \\
\end{array}$ \\
\hline $\begin{array}{l}\text { Industry dummies } \\
\text { Year dummies }\end{array}$ & & $\begin{array}{l}\text { Included } \\
\text { Included }\end{array}$ & $\begin{array}{l}\text { Included } \\
\text { Included } \\
\end{array}$ & & $\begin{array}{l}\text { Included } \\
\text { Included }\end{array}$ & $\begin{array}{l}\text { Included } \\
\text { Included }\end{array}$ \\
\hline $\begin{array}{l}\text { Mean of VIF } \\
\text { Adj. } \mathrm{R}^{2} \\
\mathrm{~F} \\
\mathrm{n}\end{array}$ & & $\begin{array}{c}1.62 \\
0.43 \\
20.47 * * * \\
837 \\
\end{array}$ & $\begin{array}{c}1.62 \\
0.43 \\
20.34 * * * \\
837 \\
\end{array}$ & & $\begin{array}{l}1.63 \\
0.22 \\
8.64 * * * \\
837 \\
\end{array}$ & $\begin{array}{l}1.62 \\
0.22 \\
8.43 * * * \\
837 \\
\end{array}$ \\
\hline
\end{tabular}

\section{Sample Data of Disclosed CSR Score}

Using the period of 2005-2010 data, in Panel A of Table 7, the result of Model 1 shows that the estimated coefficient of CSR is positive and significant $(0.086, \mathrm{p}<0.05)$ in explaining TOBINQ consistent with the results of prior studies. On the other hand, Model 2 presents that $A D J \_C S R$ is positive but insignificant $(0.046, \mathrm{p}>0.10)$. CSR activities are not related to TOBINQ when $A D J C S R$ is used to measure the level of CSR activities. Models 3 and 4 use $\boldsymbol{R O} \boldsymbol{A}$ as dependent variable. The result shows that the coefficient $(0.123, \mathrm{p}<0.01)$ of $C S R$ is significantly positive with $R O A$, consistent with the results of prior studies. However, the coefficient of $A D J C S R$ is positive and marginally significant $(0.076, \mathrm{p}<0.10)$, implying that CSR activities are not related to ROA when $A D J C S R$ is used to measure the level of CSR activities, implying that beta coefficient decreases together with the lower statistical significance level when $A D J C S R$ is used as an independent variable and $R O A$ is used as the dependent variable for CFP.

Using the period of 2005-2009 data, in Panel B of Table 7, the result of Model 1 shows that the estimated coefficient of $C S R$ is positive and significant $(0.079, \mathrm{p}<0.10)$ in explaining $T O B I N Q$, whereas Model 2 presents that $A D J C S R$ is positive but insignificant $(0.036, \mathrm{p}>0.10)$. Models 3 and 4 use $\boldsymbol{R} \boldsymbol{O} \boldsymbol{A}$ as dependent variable. The result of Model 3 shows that the coefficient $(0.129, \mathrm{p}<0.05)$ of $C S R$ is significantly positive with $R O A$, whereas the result of Model 4 reports that the coefficient of $A D J C S R$ is positive but insignificant $(0.074, \mathrm{p}>0.10)$. These results imply that CSR activities are not related to TOBIN $Q$ and ROA when ADJ_CSR is used. Using the period of 2005-2008 
data, In Panel $\mathrm{C}$ of Table 7, the results remain qualitatively unchanged. Considering the sample size is smaller, we omit reporting and interpreting of the results.

In sum, we confirm that using the sample data of disclosed CSR score to the public the results are consistent with prior studies using unadjusted CSR score. We also observe that the relationship between $C S R$ and CFP significantly weakens when ADJ_CSR is used.

Table 7. Regressions of Financial Performance on Unadjusted \& Adjusted CSR_SCORE

\begin{tabular}{|c|c|c|c|c|c|c|}
\hline \multicolumn{7}{|c|}{ Using sample of disclosed CSR score to the public } \\
\hline & & Model 1 & Model 2 & & Model 3 & Model 4 \\
\hline & & \multicolumn{5}{|c|}{ Dependent variables } \\
\hline & & TOBINQ & TOBINQ & & $\boldsymbol{R O} \boldsymbol{A}$ & $R O A$ \\
\hline Independent variables & Sign & $\begin{array}{c}\text { Coefficient } \\
\text { (t-stat) }\end{array}$ & $\begin{array}{c}\text { Coefficient } \\
\text { (t-stat) }\end{array}$ & Sign & $\begin{array}{c}\text { Coefficient } \\
\text { (t-stat) }\end{array}$ & $\begin{array}{c}\text { Coefficient } \\
\text { (t-stat) }\end{array}$ \\
\hline \multicolumn{7}{|c|}{ Panel A: Sample period: $2005-2010$} \\
\hline$C S R$ & + & $\begin{array}{c}0.086^{* *} \\
(2.27)\end{array}$ & & + & $\begin{array}{c}0.123 * * * \\
(2.63)\end{array}$ & \\
\hline ADJ_CSR & + & & $\begin{array}{l}0.046 \\
(1.31) \\
\end{array}$ & + & & $\begin{array}{l}0.076^{*} \\
(1.72)\end{array}$ \\
\hline Adj. $R^{2}$ & & 0.43 & 0.43 & & 0.23 & 0.22 \\
\hline $\mathrm{n}$ & & 812 & 812 & & 812 & 812 \\
\hline \multicolumn{7}{|c|}{ Panel B: Sample period: 2005-2009 } \\
\hline CSR & + & $\begin{array}{c}0.079^{*} \\
(1.84)\end{array}$ & & + & $\begin{array}{c}0.129 * * \\
(2.39)\end{array}$ & \\
\hline ADJ_CSR & + & & $\begin{array}{l}0.036 \\
(0.91) \\
\end{array}$ & + & & $\begin{array}{l}0.074 \\
(1.45)\end{array}$ \\
\hline $\begin{array}{l}\text { Adj. } R^{2} \\
n\end{array}$ & & $\begin{array}{l}0.42 \\
667\end{array}$ & $\begin{array}{l}0.42 \\
667\end{array}$ & & $\begin{array}{l}0.24 \\
667\end{array}$ & $\begin{array}{l}0.23 \\
667\end{array}$ \\
\hline \multicolumn{7}{|c|}{ Panel C: Sample period: $2005-2008$} \\
\hline CSR & + & $\begin{array}{l}0.044 \\
(0.96)\end{array}$ & & + & $\begin{array}{c}0.183 * * * \\
(3.39)\end{array}$ & \\
\hline$A D J \_C S R$ & + & & $\begin{array}{l}0.012 \\
(0.29) \\
\end{array}$ & + & & $\begin{array}{c}0.110^{* *} \\
(2.15) \\
\end{array}$ \\
\hline Adj. $R^{2}$ & & 0.43 & 0.43 & & 0.27 & 0.26 \\
\hline $\mathrm{n}$ & & 533 & 533 & & 533 & 533 \\
\hline Control variables & & Included & Included & & Included & Included \\
\hline Industry dummies & & Included & Included & & Included & Included \\
\hline Year dummies & & Included & Included & & Included & Included \\
\hline
\end{tabular}

\section{Summary of Empirical Results}

Table 8 summarizes the empirical results when the unadjusted and adjusted CSR scores are used. In Panel A of Table 8, using the sample of disclosed and undisclosed CSR score when we use unadjusted CSR score, the coefficients on $C S R$ for TOBINQ are positive and significant in all sample periods $(0.098, \mathrm{p}<0.01 ; 0.105, \mathrm{p}<0.01$, and $0.073, \mathrm{p}<0.10$, respectively) supporting the results of prior studies. However, when adjusted CSR score is used, the coefficients on CSR for TOBINQ are positive but smaller, and the significance level gets weaker or insignificant in all sample periods $(0.063, \mathrm{p}<0.05 ; 0.067, \mathrm{p}<0.10$, and $0.040, \mathrm{p}>0.10$, respectively) suggesting that adjusted CSR score weakens the positive relationship between CSR and Tobin's Q compared to unadjusted CSR score as expected. Moreover, in Panel B, Table 8, based on the sample of disclosed CSR score, we confirm that the results of adjusted CSR score $(0.086, \mathrm{p}<0.05 ; 0.079, \mathrm{p}<0.10 ; 0.044, \mathrm{p}>0.10$, respectively) weakens the positive relationship between CSR and Tobin's Q compared to those of unadjusted CSR score $(0.046, \mathrm{p}>0.10 ; 0.036, \mathrm{p}>0.10 ; 0.012, \mathrm{p}>0.10$, respectively) as predicted. 
When we use the unadjusted CSR score, the coefficients of CSR on ROA are positive and significant in all sample periods $(0.079, \mathrm{p}<0.05 ; 0.094, \mathrm{p}<0.05$, and $0.121, \mathrm{p}<0.05$, respectively) which are also supporting the results of prior studies. However, when adjusted CSR score is used, the coefficients of CSR on ROA are positive but smaller, and the significance level gets insignificant in all sample periods $(0.040, \mathrm{p}>0.10 ; 0.044, \mathrm{p}>0.10$, and 0.063 , $\mathrm{p}>0.10$, respectively), implying that adjusted CSR score significantly weakens the positive relationship between CSR and ROA compared to unadjusted CSR score. In addition, in Panel B, Table 8, based on the sample of disclosed CSR score, we confirm that the results of adjusted CSR score $(0.123, \mathrm{p}<0.01 ; 0.129, \mathrm{p}<0.05$, and 0.183 , $\mathrm{p}<0.01$, respectively) weakens the positive relationship between CSR and ROA compared to those of unadjusted CSR score $(0.076, \mathrm{p}<0.10 ; 0.074, \mathrm{p}>0.10$, and $0.110, \mathrm{p}<0.05$, respectively) as expected.

Taken together, we confirm that potential measurement problem in unadjusted CSR scores in testing the CSR-CFP relation seems to exaggerate the positive relationship between CSR and CFP. Specifically, unadjusted CSR scores make the relationship between CSR and CFP more positive than adjusted CSR scores because unadjusted KEJI CSR score includes operating performance measures that are highly correlated with CFP.

Table 8. Summary of empirical results

\begin{tabular}{|c|c|c|c|}
\hline \multicolumn{4}{|c|}{ Panel A. Full sample data including disclosed and undisclosed CSR score to the public } \\
\hline & & ample perio & \\
\hline & 2005-2010 & 2005-2009 & 2005-2008 \\
\hline Independent variable & \multicolumn{3}{|c|}{ Dependent variable: TOBINQ } \\
\hline $\begin{array}{l}\text { CSR } \\
\text { ADJ_CSR }\end{array}$ & $\begin{array}{l}0.098 * * * \\
0.063 * *\end{array}$ & $\begin{array}{c}0.105 * * * \\
0.067 * \\
\end{array}$ & $\begin{array}{c}0.073^{*} \\
0.040\end{array}$ \\
\hline Independent variable & \multicolumn{3}{|c|}{ Dependent variable: ROA } \\
\hline $\begin{array}{l}\text { CSR } \\
\text { ADJ_CSR }\end{array}$ & $\begin{array}{c}0.079 * * \\
0.040 \\
\end{array}$ & $\begin{array}{c}0.094 * * \\
0.044\end{array}$ & $\begin{array}{c}0.121^{* *} \\
0.063 \\
\end{array}$ \\
\hline $\mathrm{n}$ & 1,301 & 1,053 & 837 \\
\hline \multicolumn{4}{|c|}{ Panel B. Sample data including disclosed CSR score to the public } \\
\hline & \multicolumn{3}{|c|}{ Sample period } \\
\hline & 2005-2010 & 2005-2009 & 2005-2008 \\
\hline Independent variable & \multicolumn{3}{|c|}{ Dependent variable: TOBINQ } \\
\hline $\begin{array}{l}\text { CSR } \\
\text { ADJ_CSR }\end{array}$ & $\begin{array}{c}0.086^{* *} \\
0.046 \\
\end{array}$ & $\begin{array}{c}0.079^{*} \\
0.036 \\
\end{array}$ & $\begin{array}{l}0.044 \\
0.012 \\
\end{array}$ \\
\hline Independent variable & \multicolumn{3}{|c|}{ Dependent variable: ROA } \\
\hline $\begin{array}{l}\text { CSR } \\
\text { ADJ_CSR }\end{array}$ & $\begin{array}{c}0.123 * * * \\
0.076^{*}\end{array}$ & $\begin{array}{c}0.129^{* *} \\
0.074 \\
\end{array}$ & $\begin{array}{c}0.183^{* * *} \\
0.110^{* *}\end{array}$ \\
\hline $\mathrm{n}$ & 812 & 667 & 533 \\
\hline
\end{tabular}

\section{SUMMARY AND CONCLUSION}

In this study, we examine whether CSR activities are really profitable by enhancing firm value and increase ROA when adjusted CSR score is used. Considering KEJI index is widely used in the studies that explore the relationship between CSR and CFP in Korea setting, we investigate whether the original CSR score measured by KEJI index results in upward bias in the relationship between CSR and CFP due to potential measurement problem. In business practice, whether or not CSR is positively associated with CFP is an important issue for a firm's managers. If CSR is positively related to CFP, managers are motivated to pursue CSR activities proactively. In contrast, if CSR is negatively associated with CFP, managers need to be cautious to invest in CSR activities. Given CSR score is an important factor in the relationship between CSR and CFP, it is meaningful to explore the potential measurement problem of KEJI CSR score. To do this we employ adjusted CSR score obtained by excluding the performance-related component (i.e. economic development contribution) from the original CSR score to see the degree of distortion in the positive CSR-CFP relation when the original (unadjusted) CSR score is used.

CSR activities are measured using unadjusted and adjusted CSR scores based on KEJI index to compare both empirical results. CFP is measured using Tobin's Q and ROA widely employed in the prior studies. Using a 
sample of 1,301 firm-year observations of Korean manufacturing public firms during the period of 2005-2010, the results show that adjusted CSR score excluding operating performance component from KEJI index significantly weakens the positive relationship between CSR and CFP compared to unadjusted CSR score in Korea, suggesting that researchers and managers reconsider the importance of using the proper CSR measure depending on the research question of interest.

Like all empirical studies, our study has several limitations. First, as pointed out by Waddock and Graves (1997) in the CSR studies, this study still might have measurement problem issues even though we use adjusted CSR scores. Second, we restrict the sample to listed manufacturing firms in KOSPI market because KEJI provide only KOSPI firms with CSR scores. One should be careful to apply this result to small and medium (SME) firms.

Despite these limitations, we believe that the results of this study have important implications for managers and researchers. First, it is meaningful for managers to recognize that the positive CSR-CFP relationship reported in the majority of prior studies seem to be exaggerated and can be discounted to some extent due to the potential measurement problem in the original CSR scores used in those studies.

Second, to researchers, this study suggests that measurement problem of CSR score might distort the relationship between two variables. That is, operating performance component included in CSR score causes to produce a positive upward bias to the CSR-CFP relationship due to the high positive correlation between operating performance component and CFP. In particular, our main results show that the relationship between CSR and CFP significantly weakens when we use adjusted CSR score correcting measurement problem. This finding is strongly supported by sensitive tests using top 200 CSR scores firms mostly used in prior studies. Thus, this finding is likely to help researchers interpret conservatively or differently the previous results of CSR-CFP relationship, which used unadjusted CSR score.

In conclusion, this study drives researchers to recognize the importance of appropriate measurement of CSR activities to examine the relationship between CSR and CFP. Therefore, when they investigate the relationship between CSR and CFP using previous KEJI CSR score data including the periods before 2010 on the fiscal year basis, we strongly suggest that they use adjusted CSR score to measure the level of CSR activities in Korea. Then, assuming using adjusted CSR score, we want to ask again, "Is CSR really profitable in Korea?"

In future study, they may extend this research by finding other measurement problems of CSR score to explain the reasons of mixed or biased results of CSR-CFP relationship. CSR score and performance measurement issues between CSR and CFP need to be revisited in more detail.

\section{AUTHOR INFORMATION}

Eunho Cho, Ph.D. and Assistant Professor of Accounting has been teaching at Nanjing Campus of New York Institute of Technology since September, 2015. He was an Adjunct Professor at Sogang University from 2012 and a lecturer at Korea Banking Institution from 2004, respectively. He obtained Accounting doctor degree at Sogang University on Feb. 2015. He received the Master of Financial Engineering degree from KAIST. He also worked for finance and manufacturing company for 9 years and 4 years, respectively. His research focuses on the CSR, earnings management, corporate governance, international business, and valuation. He achieved the certificate of CFA, AICPA and FRM which are conferred by US based institutions. Eunho Cho, New York Institute of Technology, Nanjing Campus, P.O.B. 694 \#9 Wenyuan Lu, Qixia District Nanjing University of Post and Telecommunications College of Overseas Education, Nanjing Jiangsu 210023, PRC. E-mail: ehcho@ nyit.edu (Main author).

Hayeon Park, Ph.D candidate has been majoring the Accounting to achieve doctor degree at Sogang University since 2011. She received the MBA degree from Sogang University. Her research interests are primarily in the areas of earnings management, corporate governance, and CEO. Hayeon Park, School of Business, Sogang University, 35 Baekbumro Mapogu, Seoul, Korea, 121-742. E-mail: hyp21@,sogang.ac.kr (Corresponding author). 


\section{REFERENCES}

Aguinis, H., \& Glavas, A. (2012). What we know and don't know about corporate social responsibility: A review and research agenda. Journal of Management, 38(4), 932-968.

Akpinar, A., Jiang, Y., Gómez-Mejía, L. R., Berrone, P., \& Walls, J. L. (2008). Strategic use of CSR as a signal for good management. IE Business School Working Paper, 1-24.

Arlow, P., \& Gannon, M. J. (1982). Social responsiveness, corporate structure, and economic performance. Academy of Management Review, 7(2), 235-241.

Barnett, M. L. (2007). Stakeholder influence capacity and the variability of financial returns to corporate social responsibility. Academy of Management Review, 32(3), 794-816.

Beurden, P., \& Gössling, T. (2008). The worth of values - A literature review on the relation between corporate social and financial performance. Journal of Business Ethics, 82(2), 407-424.

Bhagat, S., \& Bolton, B. (2008). Corporate governance and firm performance. Journal of Corporate Finance, 14(3), 257-273.

Black, B. S., Jang, H., \& Kim, W. (2006). Does corporate governance predict firms' market values? Evidence from Korea. Journal of Law, Economics, and Organization, 22(2), 366-413.

Bragdon Jr, J. H., \& Marlin, J. A. (1972). 1s pollution profitable? Risk Management, 19, 9-18.

Cho, E. H., \& Chun, S. B. (2015). Corporate social responsibility, real activities earnings management, and corporate governance: Evidence from Korea. Asia Pacific Jounal of Accounting \& Economics, Forthcoming.

Choi, B. B., Lee, D., \& Park, Y. (2013). Corporate social responsibility, corporate governance and earnings quality: Evidence from Korea. Corporate Governance: An International Review, 21(5), 447-467.

Choi, H., \& Moon, D. (2013). The relationship between corporate social responsibilities and accounting transparency. Korean Accounting Review, 38(1), 135-171.

Choi, J.-S., Kwak, Y.-M., \& Choe, C. (2010). Corporate social responsibility and corporate financial performance: Evidence from Korea. Australian Journal of Management, 35(3), 291-311.

Claessens, S., \& Yurtoglu, B. B. (2013). Corporate governance in emerging markets: A survey. Emerging Markets Review, 15, 1-33. doi: 10.1016/j.ememar.2012.03.002

Cochran, P. L., \& Wood, R. A. (1984). Corporate social responsibility and financial performance. Academy of Management Journal, 27(1), 42-56.

De, S. (1992). Diversification patterns and long-term corporate performance. Managerial and Decision Economics, 13(1), 1-13.

Demsetz, H., \& Lehn, K. (1985). The structure of corporate ownership: Causes and consequences. The Journal of Political Economy, 1155-1177.

Dowell, G., Hart, S., \& Yeung, B. (2000). Do corporate global environmental standards create or destroy market value? Management Science, 46(8), 1059-1074.

Drobetz, W., Schillhofer, A., \& Zimmermann, H. (2004). Corporate governance and expected stock returns: Evidence from Germany. European Financial Management, 10(2), 267-293.

Freeman, R. E. (1984). Strategic management: A stakeholder approach: Pitman.

Friedman, M. (1970, September 13th). The social responsibility of business is to increase its profit. New York Times Magazine, 32-33.

Goll, I., \& Rasheed, A. A. (2004). The moderating effect of environmental munificence and dynamism on the relationship between discretionary social responsibility and firm performance. Journal of Business Ethics, 49(1), 41-54.

Graves, S. B., \& Waddock, S. A. (1994). Institutional owners and corporate social performance. Academy of Management Journal, 37(4), 1034-1046.

Heo, M., \& Chung, K. (2010). A study on relationship between CSR performance and corporate value: Focus on mediation effect of corporate reputation. Korean Journal of Industrial Economics and Business, 23(2), 749771.

Hull, C. E., \& Rothenberg, S. (2008). Firm performance: The interactions of corporate social performance with innovation and industry differentiation. Strategic Management Journal, 29(7), 781-789.

Jang, J., \& Choi, H. (2010). The relation between corporate social responsibility and financial performance. Korean Journal of Business Administration, 23(2), 633-649.

KEJI. (2011). The 20th corporate award of economic justice: Korea Economic Justice Institute. 
KEJI. (2012). The 21th corporate award of economic justice: Korea Economic Justice Institute.

Kim, C. (2009). Corporate social responsibility and firm value. Korean Journal of Financial Studies, 38(4), 507545.

Kim, C. H., Amaeshi, K., Harris, S., \& Suh, C.-J. (2013). CSR and the national institutional context: The case of South Korea. Journal of Business Research, 66(12), 2581-2591. doi: 10.1016/j.jbusres.2012.05.015

Kim, Y., Park, M. S., \& Wier, B. (2012). Is earnings quality associated with corporate social responsibility? The Accounting Review, 87(3), 761-796. doi: 10.2308/accr-10209

Kim, Y., \& Wee, J. (2011). Comprehensive analysis of corporate social responsibility. Korean Journal of Business Administration, 24(5), 2913-2950.

Kook, C., \& Kang, Y. (2011). Corporate social responsibility, corporate governance, and firm value. Korean Journal of Financial Studies, 40(5), 713-748.

Lien, Y.-C., \& Li, S. (2013). Does diversification add firm value in emerging economies? Effect of corporate governance. Journal of Business Research, 66(12), 2425-2430.

Margolis, J. D., \& Walsh, J. P. (2001). People and profits?: The search for a link between a company's social and financial performance.

Mattingly, J. E., \& Berman, S. L. (2006). Measurement of corporate social action discovering taxonomy in the Kinder Lydenburg Domini ratings data. Business \& Society, 45(1), 20-46.

McGuire, J. B., Sundgren, A., \& Schneeweis, T. (1988). Corporate social responsibility and firm financial performance. Academy of Management Journal, 31(4), 854-872.

McWilliams, A., \& Siegel, D. (2000). Corporate social responsibility and financial performance: Correlation or misspecification? Strategic Management Journal, 21(5), 603-609.

Moore, G. (2001). Corporate social and financial performance: an investigation in the UK supermarket industry. Journal of Business Ethics, 34(3-4), 299-315.

Moskowitz, M. (1972). Choosing socially responsible stocks. Business and Society Review, 1(1), 71-75.

$\mathrm{Na}$, Y., \& Hong, S. (2011). An empirical analysis on value relevance of corporate social responsibility activities by firm size. Korean Accounting Journal, 20(5), 125-160.

Oh, W. Y., Chang, Y. K., \& Martynov, A. (2011). The effect of ownership structure on corporate social responsibility: Empirical evidence from Korea. Journal of Business Ethics, 104(2), 283-297.

Peloza, J. (2009). The challenge of measuring financial impacts from investments in corporate social performance. Journal of Management, 35(6), 1518-1541.

Perrini, F., Russo, A., Tencati, A., \& Vurro, C. (2011). Deconstructing the relationship between corporate social and financial performance. Journal of Business Ethics, 102(1), 59-76.

Porter, M. E. (1985). Competitive advantage: creating and sustaining superior performance. New York: Free Press.

Ruf, B. M., Muralidhar, K., Brown, R. M., Janney, J. J., \& Paul, K. (2001). An empirical investigation of the relationship between change in corporate social performance and financial performance: A stakeholder theory perspective. Journal of Business Ethics, 32(2), 143-156.

Schnietz, K. E., \& Epstein, M. J. (2005). Exploring the financial value of a reputation for corporate social responsibility during a crisis. Corporate Reputation Review, 7(4), 327-345.

Seifert, B., Morris, S. A., \& Bartkus, B. R. (2004). Having, giving, and getting: Slack resources, corporate philanthropy, and firm financial performance. Business \& Society, 43(2), 135-161.

Shin, H.-H., \& Stulz, R. M. (1998). Are internal capital markets efficient? Quarterly Journal of Economics, 113(2), 531-552.

Spicer, B. H. (1978). Investors, corporate social performance and information disclosure: An empirical study. The Accounting Review, 53(1), 94-111.

Stanwick, P., \& Stanwick, S. (1998). The relationship between corporate social performance, and organizational size, financial performance, and environmental performance: An empirical examination. Accounting, Organizations and Society, 17(6), 596-612.

Strike, V. M., Gao, J., \& Bansal, P. (2006). Being good while being bad: Social responsibility and the international diversification of US firms. Journal of International Business Studies, 37(6), 850-862.

Waddock, S. A., \& Graves, S. B. (1997). The corporate social performance-Financial performance link. Strategic Management Journal, 8(4), 303-319. 


\begin{tabular}{|c|c|}
\hline Variable & Definition \\
\hline \multicolumn{2}{|r|}{ Dependent Variables } \\
\hline TOBINQ & $\begin{array}{l}\text { (market value of common and preferred stock }+ \text { long term liabilities) / book value of total assets, at } \\
\text { fiscal year-end in period } t \text {; and }\end{array}$ \\
\hline$R O A$ & operating income divided by total assets at fiscal year-end in period $t$. \\
\hline \multicolumn{2}{|r|}{ Variable of Interest } \\
\hline$C S R$ & $\begin{array}{l}\text { natural logarithm of unadjusted total CSR score measured by KEJI Index (detailed information is } \\
\text { provided in Appendix B); and }\end{array}$ \\
\hline$A D J \_C S R$ & $\begin{array}{l}\text { natural logarithm of adjusted CSR score (unadjusted total score - economic development } \\
\text { contribution included in unadjusted total CSR score). }\end{array}$ \\
\hline \multicolumn{2}{|r|}{ Control Variables } \\
\hline SIZE & natural logarithm of total asset; \\
\hline LEVERAGE & total liability / total assets; \\
\hline$A D J \_R O A$ & $\begin{array}{l}\text { industry mean-adjusted ROA in the previous year }(\mathrm{ROA}=\text { income before extraordinary items / } \\
\text { lagged total assets); }\end{array}$ \\
\hline RISK & standard deviation of prior 5 years EBITDA/total assets ${ }^{1)}$ \\
\hline FIRM AGE & natural logarithm of $(1+$ the number of years since the firm's establishment $)$ \\
\hline GOVERN & natural logarithm of governance score provided by Korea Corporate Governance Service; \\
\hline IND & industry dummy based on two-digit Korea standard industry classification code; and \\
\hline$Y E A R$ & year dummy. \\
\hline \multicolumn{2}{|r|}{ Other Variables } \\
\hline ECONO_CONT & $\begin{array}{l}\text { economic development contribution components included in KEJI index (detailed information is } \\
\text { provided in Appendix B). }\end{array}$ \\
\hline
\end{tabular}

Appendix B. KEJI Index Measurement

\begin{tabular}{|c|c|c|}
\hline Item (Score) & Subsection & Score \\
\hline \multirow{3}{*}{ Soundness of capital structure (20) } & Soundness of shareholder's composition & 7 \\
\hline & Soundness of investment expenditures & 3 \\
\hline & Soundness of capital financing & 10 \\
\hline \multirow{2}{*}{ Fairness of trades (11) } & Fair trade & 3 \\
\hline & Transparency & 8 \\
\hline \multirow{2}{*}{ Social contribution (7) } & Protection of underprivileged class of people & 4 \\
\hline & Social contribution & 3 \\
\hline \multirow{3}{*}{ Customer protection \& satisfaction (7) } & Protection of consumer right & 2 \\
\hline & Product quality & 3 \\
\hline & Advertisement expenditure & 2 \\
\hline \multirow{3}{*}{ Environmental protection activity (10) } & Environmental improvement & 4 \\
\hline & Environmental friendly policy & 3 \\
\hline & Violation and pollution & 3 \\
\hline \multirow{3}{*}{ Employee satisfaction (10) } & Health and safety of workplace & 2 \\
\hline & Investment of human resource & 4 \\
\hline & Wage and welfare & 4 \\
\hline \multirow{2}{*}{ Economic development contribution $(10)^{1}$} & Research and development efforts & 3 \\
\hline & Business performance and contribution to economic growth & 7 \\
\hline & 75 \\
\hline
\end{tabular}




\section{ENDNOTES}

${ }^{\mathrm{i}}$ Economic development contribution (10 points) specifically consists of research and development expenditure (2 points), patents ( 1 point), profitability ( 1 point), growth ( 1 point), equipment investment ( 1 point), tax payment (1 point), dividend payout ratio (1 point), labor productivity increase rate (1 point), and export contribution (1 point).

${ }^{i i}$ MSCI KLD 400 Social Index consisting of 400 companies selected from the MSCI USA Investable Market Index (IMI) also contains 5 categories: environment, community and society, employee and supply chain, customers, and governance and ethics. Website: http://www.msci.com/resources/products/indexes/thematic/esg/MSCI_KLD_ 400_Social_Index_Methodology_Feb2011.pdf

${ }^{\text {iii }}$ KEJI provides CSR scores only to KOSPI firms.

${ }^{\text {iv }}$ Freeman (1984, p. 46) defines stakeholders as "any group or individual who can affect, or is affected by, the achievement of a corporation's purpose. Stakeholders include employees, customers, suppliers, stockholders, banks, environmentalists, government, and other groups who can help or hurt the corporation."

${ }^{\mathrm{v}}$ KEJI discloses just the 200 top CSR score firms annually to the public. However, we use the CSR scores of more than 300 firms each year that include undisclosed firms to enhance better construct validity for the empirical results by securing larger sample as best as we can.

${ }^{\text {vi }}$ Economic development contribution (ECONOMIC) (10 points) specifically consists of research and development expenditure ( 2 points), patents ( 1 point), profitability ( 1 point), growth ( 1 point), equipment investment ( 1 point), tax payment ( 1 point), dividend payout ratio ( 1 point), labor productivity increase rate (1 point), and export contribution (1 point).

vii In this study, we measure CSR activities by converting CSR score into natural logarithm of CSR score to scale down to align with other variables.

${ }^{\text {viii }}$ NICE GROUP, previously known as National Information \& Credit Evaluation was founded in 1986 and started a comprehensive credit information service in 1989 for the first time in Korea. It signed strategic agreement on joint development of global platform with D\&B (Dun \& Bradstreet) (NICE GROUP Website http://eng.nice.co.kr/main.nice).

${ }^{\mathrm{ix}}$ EBITDA stands for earnings before interests, taxes, depreciation, and amortization.

${ }^{x}$ We also conduct the regression analysis using unwinsorized variables, resulting in similar results, which are not shown in this paper.

${ }^{x i}$ Since the results of control variables in Model 1 are almost the same as that of Model 2, We only interpret the coefficient of control variables in Model 1.

xii The sample in the prior studies (J.-S. Choi et al., 2010; Heo \& Chung, 2010; Jang \& Choi, 2010; Y Kim \& Wee, 2011; Na \& Hong, 2011) include 200 firms whose CSR data is disclosed to the public, whereas we use more than 300 firms in the sample that includes both disclosed and undisclosed firms to the public. Moreover, the different, extended, and recent sample period of 2005-2010 seems to be related to different results. In addition, different sampling methods that restrict the sample data to the manufacturing industry may cause to have different results (refer to Table 1).

xiii KEJI discloses CSR scores for only 200 firms even if they have CSR scores for more than 300 firms because firms rated by low CSR scores may face a reputational risk, resulting in damage to their firm value. Considering CSR activities are voluntary, KEJI might decide not to punish but to encourage CSR activities by announcing firms rated by somewhat higher CSR scores, namely top 200 firms. 


\section{NOTES}

